\title{
A Review on Consequential Life Cycle Assessment in the Power Sector
}

\author{
Le Quyen Luu $^{1,2}$, Sonia Longo ${ }^{1 *}$, Maurizio Cellura ${ }^{1}$, Eleonora Riva Sanseverino ${ }^{1}$ \\ ${ }^{1}$ Department of Engineering, University of Palermo, Viale delle Scienze Ed.9, Palermo 90128, Italy \\ ${ }^{2}$ Vietnam Academy of Science and Technology, Institute of Energy Science, 18 Hoang Quoc Viet, Cau Giay, Hanoi 10072, \\ Vietnam
}

Corresponding Author Email: sonia.longo@unipa.it

https://doi.org/10.18280/ijsdp.150802

Received: 11 September 2020

Accepted: 8 December 2020

\section{Keywords:}

CLCA, environmental impact, power sector, socio-economic interaction

\begin{abstract}
The existing policy for greenhouse gas (GHG) abatement aims at decarbonisation of the power sector. The interrelations between the power sector and other economic sectors raise a question of whether the GHG emission reduction policy in the power sector is as effective as it is claimed. Consequential life cycle assessment (CLCA) has been developed to assess the environmental impacts of any industrial/productive sector in relation with changes in the policy and its indirect impacts on other economic sectors. This review is conducted on CLCA studies in the power sector in terms of system boundaries expansion and socio-economic interactions and the ability to quantify indirect environmental impacts. It is indicated that CLCA expanded the system boundaries by applying mutatis mutandis assumption to include several affected products with various scales of change. Economic modelling tools are frequently applied to make assumptions on the extent of change. The applications of these tools also help to identify the environmental profile of product systems and the socio-economic changes such as economic growth and consumer behaviours. Thanks for the expansion of system boundaries and inclusion of socio-economic interactions, the total environmental impacts of power sector are comprehensively quantified. The variations of the total environmental impacts, with different magnitude of change, were observed in several reviewed case studies. In term of GHG emissions, some products become cleaner, for example battery; however, in most of the cases, the power system in general becomes more polluted when indirect impacts on other economic sectors are included.
\end{abstract}

\section{INTRODUCTION}

According to UNFCC, the greenhouse gas (GHG) emissions of energy sector accounted for $90 \%$ of the total GHG emissions of Annex I countries (including land use, land use change and forestation) in 2018 , at $13.47 \mathrm{GtCO}_{2} \mathrm{e}$ out of $14.91 \mathrm{GtCO}_{2} \mathrm{e}$ [1]. The power and heat generation sector, in particular, contributed to $9.76 \mathrm{GtCO}_{2} \mathrm{e}$ in 2017 and increased $2.5 \%$ in 2018 [2]. The deployment of renewable energy and energy efficiency technologies help to reduce the emission intensity by $1.3 \%$. However, the total GHG emissions of the sector generally increase due to the growing demand of power [2].

Decarbonisation, sustainable environment, economic prosperity, and social equity are the cores of the current GHG reduction policy [3]. It requires the deep decarbonisation of the economies, in which the energy system as well as other emission intensive sectors need to transform into zero emission ones, while ensuring the economic development and meeting the growing needs of population [4]. To reach the goal of decarbonisation, the industries need to reduce their GHG emission while maintaining the developing trend of the economy. The Deep Decarbonisation Pathway Project countries, which contribute to $74 \%$ of global energy-related GHG emissions, sets the objective that by 2050 the GHG emissions of energy sector will be reduced of $46-56 \%$ compared to 2010 level, while maintaining the average gross domestic product (GDP) growth of $3.1 \%$ and the population growth of $17 \%$ annually [4].

The decarbonisation process of the power sector may have some negative environmental impacts on other economic sectors. For instance, the use of bio-power may reduce the GHG emission contribution of the power sector thanks to the substitution effect for fossil-fuel-based power, but such substitution causes eutrophication and acidification due to the extensive energy crop plantation [5]. In such case, the GHG emissions of the power sector will reduce, but other negative environmental impacts within the agriculture sector will increase.

At the same time, as power and energy participate into the supply chain of every product and service, any environmental impacts of power and energy consumption or environmental benefits of energy recovery during the product life cycle will contribute to the environmental impacts or benefits of other product system. Examples in agriculture products, e.g., apples in the North of Italy, indicates that nearly $40 \%$ of climate change impacts of these products come from energy consumption during the transportation and another $40 \%$ come from power consumption during the storage of post harvesting activities [6]. An example of environmental benefits can be clearly observed in the case of waste for energy in Palermo, in which the global warming impact of conventional waste 
management system, with small amount of waste being classified and recycled, triples that of the waste management approaches with material and energy recovery [7].

Life cycle assessment (LCA) quantifies the life cycle environmental impacts of a product system, covering all stages, including raw material extraction and processing; product/ service manufacturing, use and disposal; and transportation [8]. LCA estimates the life cycle environmental burdens of a product system [8]. The comprehensiveness makes LCA a particularly effective mechanism for quantifying different environmental impacts originating from the product's life cycle including indirect impacts.

There are two types of LCA approaches, namely attributional LCA (ALCA) and consequential LCA (CLCA). In the ALCA approach, inputs and outputs of a product system are attributed to its functional unit by linking the unit processes of the system while defining a physical boundary and isolating it from other systems [9]. Meanwhile, CLCA has been developed to quantify the environmental impacts of a product system in relation with changes within its life cycle [9].

Due to the principal differences between the two approaches, it is expected that the obtained results with the application of each approach will be different. This paper reviews CLCA studies in power sector in terms of the obtained results and methodology in order to consider the capability of CLCA approach to model the indirect environmental impacts of the power system and power generation/storage technologies in the context of the existing GHG policy.

\section{METHODOLOGY}

The Glasziou's approach was applied to conduct this review with following steps: (a) developing research questions; (b) finding relevant studies; (c) appraising quality and extracting data; (d) synthesizing and (e) interpreting [10]. The searched terms were "consequential life cycle assessment AND energy sector". The broad term of energy was selected instead of power to avoid missing the studies on several topics including power, for examples, power and heat, renewable power, etc. There were 221 papers obtained from the initial search on Web of Science in January and February, 2020. These papers included different types of case study papers, methodology papers, review papers, etc.

After the initial screening to remove papers on food nutrient energy and papers studying energy as an intermediate product, there were 97 papers, which were categorized into two topics: bioenergy and power. Papers on bioenergy studied different types of bio fuels, while papers on power concentrated on different types of power, e.g., coal, natural gas thermal power, nuclear power, hydropower, renewable power, and fossil-fuelbased power with carbon capture and storage (CCS). Electric vehicles $(\mathrm{EV})$ which have recently entered the power systems scenario for regulation purposes through Vehicle to Grid (V2G) programs, was categorized as "power" topic. Papers studying power and heat simultaneously were also categorized as "power" topic.

After removing papers on "bioenergy" topic, there were 31 papers of CLCA on power sector, including both case studies and reviews. These papers were analysed in terms of their applied methodology and obtained results, e.g., system boundary, socio-economic interactions and indirect life cycle environmental impacts.

\subsection{The notion of CLCA}

The causal relationship of CLCA has been pointed out by many authors as the consequential changes in the environmentally physical flows of the product system due to any changes occurring in any processes during its life cycle [11-14]. The changes occurring during the product system's life cycle are made by decisions taken at different levels. The level at which a decision is taken is higher in case of government policies (e.g. policy to require the minimum amount of renewable power in the national power mix) or company strategies (e.g. decision on new installation of energy efficient equipment). Due to these decisions, there will be direct and consequential changes in the technological product system and its relevant life cycle environmental impacts.

Under the view of economic interactions, CLCA is defined as an approach to assess the life cycle environmental impacts due to the decrease or increase in demand on the product system $[15,16]$. The causal relationship of CLCA was connected with economic changes, for example, changes in the economic development and compulsory commitment on GHG emissions reduction cause changes in the supply and demand of the power sector, and therefore its life cycle environmental impacts.

There were several reviews on CLCA methodology and compared it with ALCA $[14,15,17]$. Other authors reviewed CLCA applications and pointed out CLCA outstanding features in capturing life cycle environmental impacts of a product system under economic interactions [18-20]. These reviews agreed on the differences of ALCA and CLCA in terms of goal and application, product system, system boundary, functional unit and allocation. The differences between CLCA and ALCA are summarized in Table 1.

\subsection{Direct and indirect life cycle environmental impacts in the power sector}

Both direct and indirect life cycle environmental impacts of power sector have been studied. The direct impacts originate from the production stage of power. The indirect impacts include two types: (1) the indirect impacts may either be situated in the intermediate products that contribute to the power's life cycle, or (2) may be originated from the affected products, which are related to the power in some ways. Some examples of the indirect impacts are land use impacts for the development of bio-electricity, impacts from equipment and power infrastructure, impacts from background processes such as primary energy, fuel extraction for power generation, impacts from increasing battery integration into the power grid due to other types of power technologies such as wind power, solar power or thermal power in the generation mix, impacts from increasing or decreasing demand on products of power intensive industries such as metal manufacturing and food processing on power grid structure and capacity.

While the indirect impacts caused by the intermediate products can be quantified with ALCA, the impacts caused by affected products should be quantified with CLCA. In this paper, the term "indirect environmental impacts" is used to denote the latter type of impacts, which originates as the consequence of changes in the product system. These changes include different types of changes in the socio-economy such as changes in the governmental policy decision, or changes in the market demand of the investigated product system or any relevant products and co-products. 
Table 1. Comparison between ALCA and CLCA [14, 18]

\begin{tabular}{|c|c|c|}
\hline Features & ALCA & CLCA \\
\hline Goal & $\begin{array}{l}\text { To assess potential environmental impacts, including inputs and } \\
\text { outputs of a product system per its functional unit over its life } \\
\text { cycle. }\end{array}$ & $\begin{array}{c}\text { To assess potential environmental impacts of a product } \\
\text { system in relation with changes per its functional unit } \\
\text { over its life cycle. }\end{array}$ \\
\hline \multirow{4}{*}{ Application } & Answer for question "How things are?" & Answer for question "What if?" \\
\hline & Hotspot identification or product comparison. & Reflection of causality. \\
\hline & ALCA is relevant when no specific decision is at hand for & Used for decision-making. \\
\hline & $\begin{array}{l}\text { increasing the understanding of the causal relations within the } \\
\text { product chain, and between this chain and the surrounding } \\
\text { technological systems. }\end{array}$ & $\begin{array}{l}\text { CLCA is relevant when rational decision-making is } \\
\text { needed. This process requires information about the } \\
\text { consequences of the decision. }\end{array}$ \\
\hline $\begin{array}{l}\text { Product } \\
\text { system }\end{array}$ & Normally there is one product system per ALCA. & $\begin{array}{l}\text { The product systems are broadened to include several } \\
\text { similar or relevant products. }\end{array}$ \\
\hline $\begin{array}{l}\text { System } \\
\text { boundary }\end{array}$ & $\begin{array}{l}\text { Over the product system's whole life cycle (from cradle to grave), } \\
\text { or a part of its life cycle (from cradle to gate, from gate to gate, } \\
\text { from gate to grave). }\end{array}$ & $\begin{array}{c}\text { The system boundary is broadened to include unit } \\
\text { processes and products as consequences of change/ } \\
\text { intervention. }\end{array}$ \\
\hline $\begin{array}{l}\text { Functional } \\
\text { unit }\end{array}$ & 1 unit of function of product system. & $\begin{array}{l}1 \text { unit of function of marginal product system. } \\
\text { Functional unit of the whole system would consist of } \\
\text { multiple functions, including the main system and } \\
\text { those added by the processes included in the } \\
\text { boundaries. }\end{array}$ \\
\hline Allocation & $\begin{array}{l}\text { The impacts are ascribed for main product and co-products based } \\
\text { on economic value (price) or physical value (volume, mass, etc.). }\end{array}$ & $\begin{array}{l}\text { System boundary is broadened to include main product } \\
\text { and co-products, so there is no need of allocation. }\end{array}$ \\
\hline
\end{tabular}

\section{RESULTS AND DISCUSSION}

\subsection{System boundary}

CLCA approach expands the studied system boundary by including different unit processes [18] and products and coproducts [21] to the extent of the expected changes. All of the reviewed case studies expanded the product system boundary by either increasing unit processes or including relevant products and co-products. Some studies made it very clear on the inclusion of extended unit processes [22-26], while others did not clearly identify the unit processes of a product system's life cycle [27-34]. In terms of products and co-products, the system boundary was extended to at least two products in all reviewed studies. Moreover, it was even extended to several relevant economic sectors. The investigated products and economic sectors of some reviewed CLCA papers are specified in Table 2.

There are two approaches for dealing with the expansion of system boundary in a CLCA, namely ceteris paribus (other things being equal) and mutatis mutandis (the necessary changes being made) assumptions. In the ceteris paribus assumption, the changes in the product system are analysed in isolation, as the scale of effect is small [35]. The products/ technologies, which are affected by the changes, are called marginal products/ technologies [36]. In contrast, the mutatis mutandis approach assumes that the changes in the product system are large enough to induce changes in other socioeconomic sectors [37].

The first assumption was proposed by Weidema [35]. The author suggested an approach to identify marginal products/ technologies in five steps $[35,38]$, including:

(1) The scale and time horizon of the study,

(2) The scale of the effect, at process or market scale,

(3) The trend in volume of the affected market,

(4) The potential of an increase or reduction in supply and demand, and

(5) The favourability of the technology.

The approach clarified not only the link between the product systems and unit processes through intermediate products, which is conveyed in an ALCA, but also the consequences on supply and demand of products and co-products [38]. A study of Mattsson et al. [38] indicated that a change in the annual power demand by $1 \mathrm{TWh}$ induced the same consequence on the power technologies as a change of $1 \mathrm{kWh}$. Therefore, the change in the annual power demand by $1 \mathrm{TWh}$ may be regarded as small. It was suggested that in case of limitation of data availability, the scale of change was assumed to be small [38].

Several examples of ceteris paribus assumption were presented in the studies of Eriksson et al. [22] and Jones et al. [39], in which the marginal products or technologies are replaced by an alternative product (Refer to Table 2). This assumption was either applied at the early time of CLCA development, when the methodology was emerging, for example in study of Eriksson et al. [22], or in CLCA studies which focused on dealing with the physical changes of the environmental impacts, for example in Jones et al.'s study [39]

In Eriksson et al.'s study, the environmental impacts of heat and power from waste incineration were calculated and compared with other competing fuels. The assumed marginal heat and power included combined heat and power (CHP) from biomass combustion, heat from biomass combustion and CHP from natural gas combustion. These marginal products were substituted with the ratio 1:1 by heat and power from waste incineration and material recycling [22].

The study of Jones et al.'s assessed the environmental consequences of increased PV uptake in UK within 30 years by three scenarios. Corresponding to these scenarios, there were changes in energy generation technologies, distribution network structure and grid operation. These changes in energy flows were quantified by using net energy analysis (NEA), and the changes in relevant environmental consequences were quantified by using CLCA [39]. The framework of NEA and CLCA was combined by setting the targets on distributed energy uptake, specifically $50 \mathrm{GW}$ PV with domestic storage, 50GW PV without domestic storage and $10 \mathrm{GW}$ PV without domestic storage. These targets were set by consulting with stakeholders, including distributed generation technology suppliers and installers, electricity network and grid operators 
and policy makers through a workshop. Environmental impacts due to the increase of distributed power such as impacts on raw material mining, manufacturing and transport infrastructure originated from increased deployment of solar PV were cutted-off. Besides, change in power consumption patterns due to integration of distributed power into buildings were excluded in the system boundary. The exclusion of these secondary impacts reduced the complexity and uncertainty of the studies without affecting the research focus of changes in power system as a whole [39].

The reviewed papers that applied the ceteris paribus assumption focused on the causal relations of change in the product system and affected product rather than socioeconomic relations between them. Therefore, these "claimed to be CLCA" studies should be regarded as using consequential concept, not a CLCA.

Frischknecht and Stucki proposed an approach to select the suitable assumption based on quantitative justifications [36]. In their approach, different modelling techniques would be applied depending on the changing agent, its potential effect and the size of studied product systems. It was suggested that if the potential consequences of the effect were small (the product system's economic size accounts for less than $0.1 \%$ or from $0.1 \%$ to $1 \%$ of the market share), the ceteris paribus assumption should be applied, whereas, the effects with large potential consequences (accounting for more than 1\%) should be approached by CLCA with mutatis mutandis assumption [36]. Although the criteria were not adequately convincing, they were the initial efforts of how to deal with system expansion in CLCA, based on quantitative economic value. Due to the small economic size of the product system, the potential effects of any change on the product system is limited in physical changes; namely, changes of quantity of environmental impacts without affecting the economic systems. If the effects are large in scale, there will be changes in economic interactions in other relevant sectors. In this case, the expansion of system boundary is necessary to accurately quantify the impact. Frischknecht and Stucki concluded that CLCA with mutatis mutandis assumption, therefore, would be relevant for quantifying impacts of important decisions on the investigated object with a relatively large economic size, for example governmental policies or strategic international organization decisions [36].

Examples of the mutatis mutandis assumption can be found in several studies [23-34, 40-45] (Refer to Table 2). In these studies, the marginal products or technologies were identified, with determined affected scales. The changes in the affected products were determined by reviewing literatures [24, 27, 30, $34,40]$, and running economic models [23, 25-34, 40-45].

Specifically, Moora and Lahtvee quantified the global warming potential of waste incinerated electricity in Baltic region by 2020 [24]. The authors calculated the net emissions of energy generation from waste incineration $\left(E_{n e t}\right)$ by subtracting the emissions of waste for electricity generation $\left(E_{\text {waste }}\right)$ from emissions caused by alternative energy production ( $\left.E_{\text {alternative }}\right)$, with following equation: $E_{\text {net }}=E_{\text {waste }}-$ $E_{\text {alternative. }}$ The alternative energy productions were identified as the marginal electricity in short term (electricity from natural gas, coal fired electricity and oil shale) and in long term (electricity from natural gas, coal fired electricity, biomass based and wind power) [24]. One limitation of the study is that the substitution ratio of marginal electricity with waste incinerated electricity is assumed as $1: 1$, which makes it inbetween ceteris paribus and mutatis mutandis assumptions as the investigated product system equals to the identified marginal products.

Mathiesen et al. assessed the environmental impacts of $10 \%$ increase of waste incineration for energy production. The affected energy technologies were various among different approaches. By looking at publications on historical and future energy system and existing CLCAs, the identified affected product was coal-fired energy. Meanwhile, with the application of an economic model, e.g., EnergyPLAN, the identified affected products were mostly energy from natural gas and a small amount of coal [27]. The author concluded that with CLCA it is impossible to identify one "single" marginal technology and one "single" marginal technology would not accurately reflect the actual operation and interactions of the power system.

Gibon et al. conducted the LCA of human health and ecological impacts of the global low-carbon electricity due to carbon emission reduction policy. The low-carbon electricity scenario was determined by analysing the existing and future power generation mixes and the technology performance from International Energy Agency reports. The improvement in material production was taken from the New Energy Externalities Development for Sustainability project. The changes in the future power system structure and fuel consumption due to the increased adoption of clean power technology was identified based on experts' opinions [30]. The life cycle inventories of these clean power technologies, with improvements in material production and power consumption, were modelled from EXIOBASE, a multi-regional input output model. It was identified that, thanks to the lower impacts on climate change, renewable energy and nuclear power cause lower human health impacts than coal or gas power. However, in term of ecological impact, the biopower had the similar ecosystem quality damage points (species.yr/kWh) as the coal power. The land occupation of biopower causes damage to the ecosystem quality at the same magnitude as the climate change impact of coal power [30].

Vandepaer et al. quantified potential environmental benefits and drawbacks of batteries integration into the future Swiss electricity supply system. The marginal electricity supply mixes were extracted from literatures of Kannan and Turton for electricity generation scenarios, publications of European Commission and International Energy Agency for electricity imports. The projections about the battery performances and the recycling process were assumed based on relevant literatures [34].

Dandres et al. assessed the environmental impacts due to European energy generation and perturbation of world economy. Different energy development scenarios of the business-as-usual (BAU) and future renewable technology mixes were taken from peer-reviewed publications of Mantzos et al. [40].

A common feature of Mathiesen et al., Gibon et al., Vandepaer et al. and Dandres et al.'s studies is that they made the assumption on the affected product by reviewing existing literatures, and combining with economic modelling, for examples EnergyPLAN [27], EXIOBASE [30], Swiss TIMES Energy Model (STEM) [34], and Global Trade Analysis Project (GTAP) [40]. 
Table 2. System boundary - product systems and affected products of some reviewed papers

\begin{tabular}{|c|c|}
\hline Studies & Investigated product systems \\
\hline $\begin{array}{l}\text { Eriksson et } \\
\text { al. [22] }\end{array}$ & $\begin{array}{l}\text { Heat generation from waste } \\
\text { incineration }\end{array}$ \\
\hline $\begin{array}{l}\text { Pizarro- } \\
\text { Alonso et } \\
\text { al. [23] }\end{array}$ & Waste to energy \\
\hline $\begin{array}{l}\text { Moora and } \\
\text { Lahtvee } \\
{[24]}\end{array}$ & $\begin{array}{l}\text { Waste incineration for electricity } \\
\text { and heat generation }\end{array}$ \\
\hline $\begin{array}{l}\text { Pehnt et al. } \\
\text { [25] }\end{array}$ & Wind power \\
\hline $\begin{array}{l}\text { Blanco et } \\
\text { al. [26] }\end{array}$ & Power to methane \\
\hline $\begin{array}{l}\text { Mathiesen } \\
\text { et al. [27] }\end{array}$ & Power and heat from waste \\
\hline $\begin{array}{l}\text { Lund et al. } \\
\text { [28] }\end{array}$ & Power \\
\hline $\begin{array}{l}\text { Igos et al. } \\
\text { [29] }\end{array}$ & $\begin{array}{l}\text { Six energy final products including } \\
\text { liquid fuels, fuels, coke, refined } \\
\text { petroleum, electricity, products of } \\
\text { mining and quarrying of energy, } \\
\text { and gas, steam and hot water }\end{array}$ \\
\hline $\begin{array}{l}\text { Gibon et } \\
\text { al. [30] }\end{array}$ & $\begin{array}{l}17 \text { energy technologies including } \\
\text { bioenergy, coal, hydropower, } \\
\text { natural gas, natural gas, } \\
\text { concentrating solar power, nuclear } \\
\text { power, solar photovoltaics (solar } \\
\text { PV), wind power and CCS }\end{array}$ \\
\hline
\end{tabular}
McDowall solar PV, coal, combined cycle gas et al. [31] turbine, conventional gas, nuclear, hydro, oil, biomass and waste

Mutatis mutandis

Mutatis mutandis

The US power system with power from coal, natural gas, nuclear,

Algunaibet hydropower, biomass, geothermal, et al. [33] solar PV, solar thermal, wind, bioenergy and CCS

Vandepaer et al. [34]

Jones et al. [39]

Mutatis mutandis

Mutatis mutandis

Ceteris paribus

Power generation technologies, distribution network and electricity
18 power technologies from wind,

Mutatis mutandis Mutatis mutandis

Mutatis mutandis

Mutatis mutandis grid operation
Mutatis mutandis
The same as investigated product systems

Different types of UK on-grid power such as wind, nuclear, coal, gas and biomass power

The same as investigated product systems

On-grid power

Power system

The same as investigated product systems
Coverage of economic sectors

Heat and power generation

Two sectors of waste management and power generation

Two sectors of waste management and power generation

\section{N/A}

The whole economic system of energy supply and demand sectors, including power, heat, industry, transport, and supply (supply); and commercial, residential, industry, mobility and agriculture (demand)

\section{N/A}

N/A

Six economic sectors of Luxembourg: Agriculture, Construction, Industry, Electricity production and distribution, Transport, and Other industries

N/A

The comprehensive energy supply and demand sectors of fuel provision sectors, power generation sectors (Agriculture, Forestry, Coal, Leather, Wood, Pulp \& Paper, Printing \& Media, Coke, Nuclear fuel, Chemicals, Rubber $\&$ Plastic products, Other non-metallic mineral products, Fabricated metal products) and power consumption sectors (Agriculture, Pulp \& Paper, Chemicals, Non-Metallic minerals and Other industry)

\section{N/A}

N/A

N/A

N/A

20 globally economic sectors: Grains and crops; Livestock and meat products; Processed food; Water; Textiles and clothing; Light manufacturing; Heavy manufacturing; Utilities and construction; Transport and

communication; Other services; Coal and lignite extraction; Gas extraction; Oil and peat extraction; Minerals; Fuels; Gas, steam and hot water; Electricity; Forestry; and Pulp, paper, publishing and Wood products 
Other authors used economic models to determine marginal technologies such as Balmorel [23], EU Electricity Market Model (E2M2) [25], JRC-EU-TIMES [26], EnergyPLAN [28], ETEM and LUXGEM [29], THEMIS and EXIOBASE [30], TIMES (ETM-UCL) and Environmentally Extended InputOutput (EEIO) [31], Unit commitment model [32], Emissions Reduction Cooperation Model [33], Sequential Quadratic Programming algorithm [41], MARKAL [42], Network Impact Assessment Model [43], Agent Based Modelling (ABM) [44] and System Dynamics (SD) [45]. The results of the studies that applied economic models will be presented in the following parts.

Under the mutatis mutandis assumption, the number of identified affected products does not limit in one product, but a combination of several products (Refer to Table 2). Moreover, the scales of change are different among affected products. In other word, a change in the investigated product system causes necessary changes in various affected products. The review on system boundary and assumptions of existing literature indicated that the mutatis mutandis assumption was preferred for CLCA in power sector, and in order to determine the set of effected products to the extent of change, the application of economic modelling is useful.

\subsection{Socio-economic interactions}

According to Earles and Halog, Zamagni et al., Weidema, CLCA included the economic relations of the product system in forms of market mechanism or economic-based causal relationship [15, 18, 21]. The most common way to model the economic relationship is combining an economic modelling tool and LCA. The applicable economic models are either partial equilibrium (PE), general equilibrium (GE), input output (IO) or dynamic models (DM), which were also common in CLCA studies in the energy sector in general [46]. In power sector, two thirds of reviewed papers applied economic models to simulate the economic interactions between power sector and other sectors. The pathway for integrating these models into CLCA was running the models to obtain scenarios with changes in affected sectors and identify affected products/technologies. These scenarios and data on affected products/technologies would be used for running CLCA.

Among reviewed papers, there were ten studies using PE, two studies applying GE, five studies applying IO, and two studies applying DM. More interestingly, it was common that some studies apply several types of economic models, for example PE in combination with GE, and PE in combination with IO. The applications of PE, GE, and IO had the advantage of available data and energy models. Meanwhile, the DM was limited in terms of availability of data and modelling tools, but worked well with socio-economic data [46]. Table 3 presents the reviewed CLCA case studies and their applicable models.

The applications of several economic models, e.g., IO/ $\mathrm{PE} / \mathrm{GE}$ in CLCA provided details of the economic causal relationship [47]. PE had the advantage of conveying a specific view of one economic sector, while GE delivered a comprehensive view of the product system in relations with the economy [46]. IO can be applied to either one economic sector, e.g., EnergyPLAN for modelling power sector, or used for studying the whole economy, e.g., World Input Output Database [48].

Table 3. Applicable tools in reviewed papers

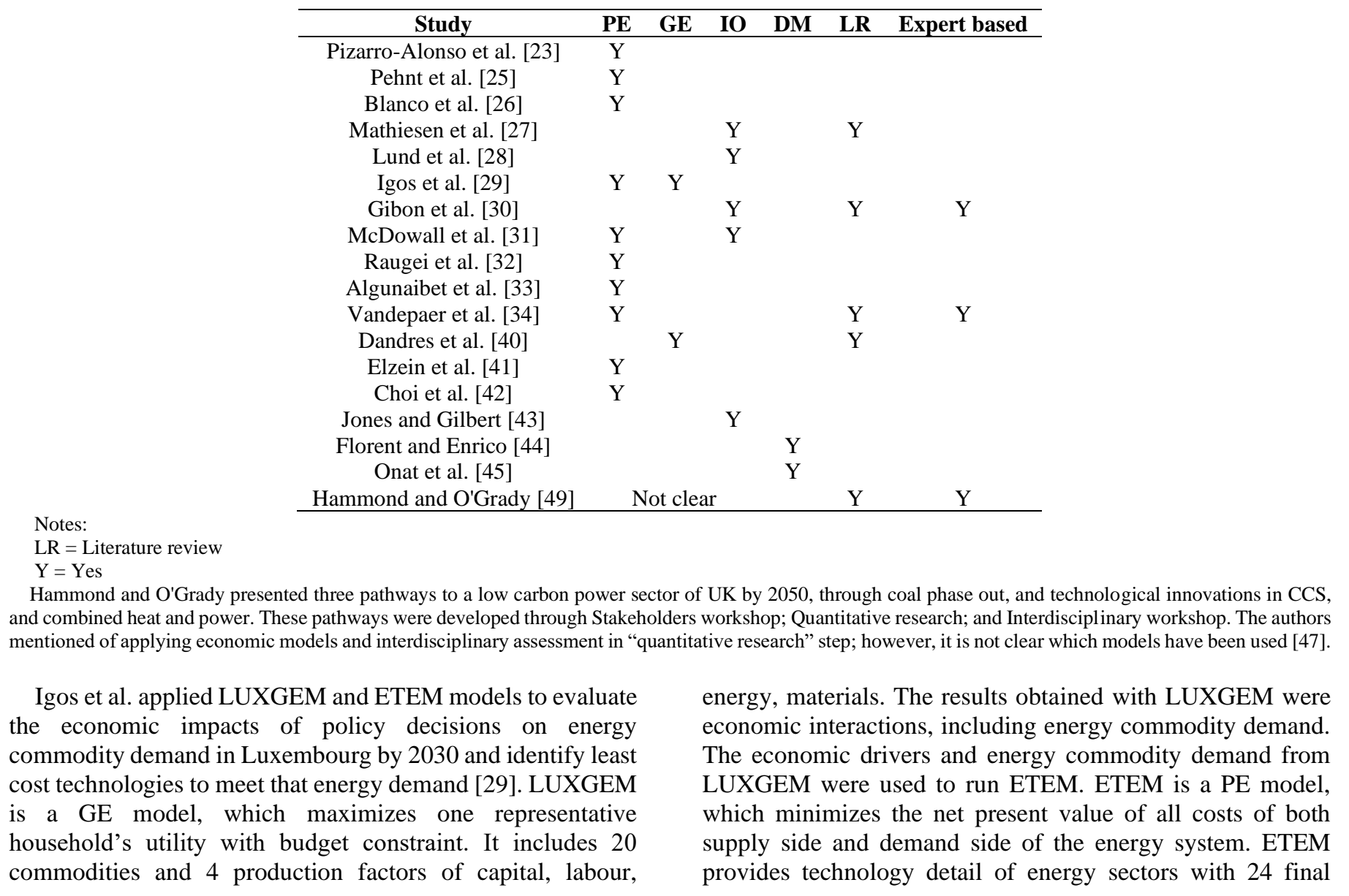


demand commodities. The simulations of LUXGEM and ETEM were repetitively conducted to obtain the same energy consumption. It was identified that the contribution of other economic sectors to the national environmental profile, except for energy sector, were quite similar. Moreover, most of the environmental impacts originated from imported commodities [29].

McDowall et al. combined ETM-UCL and EEIO to quantify indirect carbon emission of renewable energy technologies of EU energy system [31]. ETM-UCL is a PE energy development model, which optimizes energy system cost to carbon constraints. Energy demand is exogenous, based on drivers such as GDP, population, household numbers and sectorial output. The obtained result of ETM-UCL was an optimized mix of power generation technologies. EEIO was used to obtain the direct and upstream emission factors of power generation technologies. The results on changes within the power sector were specific and interesting, which indicated the reduction of solar PV deployment when the upstream emissions were included. It was the same for the renewable energy, with 4\% reduction of installed capacity by 2050 [31].

Dandres et al. applied GTAP model to predict global economic perturbation potentially caused by two different European energy policies, and CLCA to quantify environmental impacts due to these policies [40]. GTAP is a GE model, which simulates the world economy subject to changes in fuel demand, economic and technological changes. The original 57 economic sectors and 113 regions of GTAP were aggregated into 20 sectors and 14 regions. The obtained results from GTAP were comprehensive changes in production of the global economy for each region. Among economic sectors, the most impacted sector was coal extraction and power generation. Consequently, it contributed to most of the difference in the environmental impacts. Moreover, the authors pointed out that the most sensitive causal relation lied in economic revolution or the change in the GDP, rather than the change in the demand [40].

Apart from economic causal relationship, CLCA also can cover the social interrelations among the product system. In this case, the original changes were not limited to the decrease or increase of consumption and production, which are quantitative, but also include changes in social indicators. This was conducted with the application of DM such as ABM and SD.

Among the reviewed papers there were only two case studies covering the social aspects or social relationship of the power system. These studies either simulated the social agents and their impacts on the product system [44], or simulated the socio-economic interactions of the product system over its life cycle [45].

Florent and Enrico combined ABM and CLCA to model changes in vehicle private use in Luxembourg due to different mobility policies in relation with environmental impacts of battery EVs, plug-in hybrid EVs by 2020 , and compared them with gasoline internal combustion vehicles and diesel internal combustion vehicles [44]. The obtained results included qualitative changes on characteristics of travel, charging patterns and auxiliary use and quantitative indicators such as number of travels, which consequently change environmental indicators such as decrease global warming, fossil depletion, acidification, ozone depletion and photochemical ozone formation; and increase in metal depletion, ionizing radiations, marine eutrophication and particulate matter formation [44].

In Onat at el.'s study, CLCA based on SD was applied to model impacts of three alternative vehicles including internal hybrid, plug-in hybrid and battery EV by 2050 and compared them with internal combustion vehicle [45]. The increase in the utilization number of EVs caused sustainable impacts on three pillars of sustainability (environment, economy and society), including carbon dioxide emissions, particulate matter formation, photochemical oxidant formation (for environmental aspect), vehicle ownership cost, contribution to GDP (for economic aspect), employment generation, and the human health impacts (for social aspect). With CLCA approach, it was identified that EVs were expected to be the best alternative in long-term for reducing human health impacts and air pollution from transportation. Meanwhile, the result based on average value indicated that plug-in hybrid vehicles had the largest potential GHG emission reductions [45].

In the context of GHG policy intervention, more and more renewable energy sources will be integrated into the power system. The impacts of these integrations will not limit in the technical changes of the power system, and thereby its relevant environmental consequences, both positive and negative, but also cause economic and social impacts. As a result, the development of CLCA methodology with the consideration of socio-economic interactions is useful for comprehensively and precisely assessing impacts of the future power system.

\subsection{Indirect environmental impacts of the power sector}

By expansion of system boundary and inclusion of socioeconomic interactions, CLCA demonstrates its ability in quantifying indirect life cycle environmental impacts of the power sector. When the indirect environmental impacts are included, the total environmental impact points either increase or reduce. In other words, the investigated power sector becomes cleaner (increased emission reduction), less clean (decreased emission reduction), more polluted (increased emissions) or less polluted (decreased emissions). In the analysed literature, the scales of change range from $5 \%$ to $200 \%$ [50]. The difference between the life cycle environmental impacts with and without indirect impacts quantified with CLCA approach in the power sector is presented in Table 4.

Frischknecht and Stucki used attributional, decisional (consequential at micro-economic level) and consequential approaches to quantify the environmental impacts of French and EU electricity supply [37]. The attributional life cycle inventory was taken from Ecoinvent database, the most common life cycle inventory database. The decisional life cycle inventory was based on EurElectric (a publication on power statistics in European countries), other energy publications and expert opinions. The authors identified that there was a difference among the obtained results. In the French electricity supply mix, the GHG emissions calculated with attributional and decisional approach varied by $129.6 \%$, at $98 \mathrm{gCO}_{2} \mathrm{e}$ per $\mathrm{kWh}$ and $225 \mathrm{gCO}_{2} \mathrm{e}$ per $\mathrm{kWh}$, respectively. However, the volumes of high radioactive waste reduced from 11 with attributional approach to $3.8 \mathrm{~mm}^{3}$ per $\mathrm{kWh}$ with decisional approach [36]. In EU electricity supply mix, both environmental indicators of GHG emissions and high radioactive waste reduced when decisional approach was applied, from 554 to $473 \mathrm{gCO}_{2} \mathrm{e}$ per $\mathrm{kWh}$ and from 3.5 and 3.4 $\mathrm{mm}^{3}$ per $\mathrm{kWh}$, respectively [37]. The decreases of GHG emissions and high radioactive waste of the EU electricity are due to the differences between the average electricity mix and 
the decisional electricity mix, in which the latter has lower GHG emission thanks to the phasing-out of electricity from hard coal and lignite [37].

Pehnt et al. studied the increase in offshore wind power and its benefits in GHG emission reduction in Germany [25]. The change in offshore wind power capacity induced a change in the power mix, operation of power system, expansion and reinforcement of the grid. In terms of power mix, the increased offshore wind power substituted the thermal power from coal, lignite and gas. Thanks to the substitution effect, the specific carbon reductions per $\mathrm{kWh}$ offshore power in 2020 would amount to 914 and $646 \mathrm{gCO}_{2} \mathrm{e}$, in the low and high carbon certificate price scenarios, respectively [25]. At the same time, the operation of thermal power plants would be affected, adding 70 and $18 \mathrm{gCO}_{2} \mathrm{e}$ of emissions per $\mathrm{kWh}$ of off-shore wind power. The emission from wind induced grid expansion and reinforcement is $22 \mathrm{gCO}_{2} \mathrm{e}$ per $\mathrm{kWh}$. When the emissions from all processes, including construction, operation and disposal of the wind energy park, wind-influenced grid expansion, carbon reductions due to thermal power substitution and GHG emissions from altered power plant operation were added up, the net carbon reductions were 822 $\mathrm{gCO}_{2} \mathrm{e}$ per $\mathrm{kWh}$ and $606 \mathrm{gCO}_{2} \mathrm{e}$ per $\mathrm{kWh}$ [25].

Blanco et al. conducted an ex-post LCA analysis of results from a PE based energy system model called JRC - EU TIMES and estimated the 18 environmental impact indicators across five energy-related sectors of power, heating, industry, transport and supply in scenarios that achieved $80-95 \%$ GHG emission reductions by 2050 in EU28+ countries [26]. The investigated environmental impacts included climate change, fossil depletion, metal depletion, water depletion, ozone depletion, ionizing radiation, particulate matter formation, photochemical oxidant formation, terrestrial acidification, freshwater eutrophication, marine eutrophication, marine ecotoxicity, freshwater ecotoxicity, terrestrial ecotoxicity, human toxicity, natural land transformation, urban land occupation and land occupation. The results showed that the indirect GHG emissions were as large as the direct one for $80 \%$ reduction target. For $95 \%$ reduction target, the indirect GHG emissions were three times larger than the direct one [26]. As the emission reduction target increases from $80 \%$ to $95 \%$, most categories' impacts decreased by $20-40 \%$, except for toxicity which was higher at 35-100\% [26].

McDowall et al. conducted a similar study on renewable energy technologies of EU energy system. In the study, the indirect emissions contributed to less than $10 \%$ of the total emissions of power sector in EU by 2050 [31], which was a small part, especially compared to the result of Blanco et al.'s study. It should be noted that there is a difference in investigated scopes of these studies. While Blanco et al.'s study covered five energy-related sectors, the indirect emissions in McDowall et al.'s study included those from energy equipment and construction [26, 31]. Even though the indirect emission of the power sector is small in McDowall et al.'s study, its inclusion into the optimization model made the renewable power less attractive than it was expected [31].

Table 4. Direct and indirect environmental impacts of some reviewed CLCA papers

\begin{tabular}{|c|c|c|c|c|c|}
\hline Studies & $\begin{array}{l}\text { Product } \\
\text { system }\end{array}$ & $\begin{array}{c}\text { Environmental impacts/ } \\
\text { benefits }\end{array}$ & $\begin{array}{l}\text { Direct impacts } \\
\text { only }\end{array}$ & $\begin{array}{c}\begin{array}{c}\text { Indirect impacts } \\
\text { included }\end{array} \\
\end{array}$ & Variation \\
\hline \multirow{4}{*}{$\begin{array}{l}\text { Frischknecht and } \\
\text { Stucki [37] }\end{array}$} & \multirow{2}{*}{$\begin{array}{l}\text { Power } \\
\text { system } \\
\text { (French) }\end{array}$} & $\begin{array}{c}\text { GHG emissions } \\
\left(\mathrm{gCO}_{2} \mathrm{e} / \mathrm{kWh}\right)\end{array}$ & 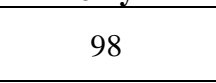 & 225 & $129.6 \%$ \\
\hline & & $\begin{array}{l}\text { High radioactive waste } \\
\left(\mathrm{mm}^{3} / \mathrm{kWh}\right)\end{array}$ & 11 & 3.8 & $-65.5 \%$ \\
\hline & \multirow{2}{*}{$\begin{array}{c}\text { Power } \\
\text { system (EU) }\end{array}$} & $\begin{array}{c}\text { GHG emissions } \\
\left(\mathrm{gCO}_{2} \mathrm{e} / \mathrm{kWh}\right)\end{array}$ & 554 & 473 & $-14.6 \%$ \\
\hline & & $\begin{array}{c}\text { High radioactive waste } \\
\left(\mathrm{mm}^{3} / \mathrm{kWh}\right)\end{array}$ & 3.5 & 3.4 & $-2.9 \%$ \\
\hline Pehnt et al. [25] & Wind power & $\begin{array}{l}\text { GHG emission reductions } \\
\left(\mathrm{gCO}_{2} \mathrm{e} / \mathrm{kWh}\right)\end{array}$ & $914 \sim 646$ & $822 \sim 606$ & $\begin{array}{c}-10.1 \% \sim \\
-6.2 \%\end{array}$ \\
\hline \multirow{2}{*}{$\begin{array}{c}\text { Blanco et al. } \\
{[26]}\end{array}$} & \multirow{2}{*}{$\begin{array}{l}\text { Energy } \\
\text { (including } \\
\text { power) }\end{array}$} & $\begin{array}{l}\text { GHG emissions }(85 \% \\
\text { emission reduction target } \\
\text { policy) }\left(\mathrm{gCO}_{2} \mathrm{e} / \mathrm{kWh}\right)\end{array}$ & \multicolumn{2}{|c|}{ N/A } & $50 \%$ \\
\hline & & $\begin{array}{l}\text { GHG emissions }(90 \% \\
\text { emission reduction target } \\
\text { policy) }\left(\mathrm{gCO}_{2} \mathrm{e} / \mathrm{kWh}\right)\end{array}$ & \multicolumn{2}{|c|}{ N/A } & $200 \%$ \\
\hline Igos et al. [29] & $\begin{array}{l}\text { Energy } \\
\text { (including } \\
\text { power) }\end{array}$ & $\begin{array}{l}\text { Human health, ecosystem } \\
\text { and resources (BAU and } \\
\text { GHG scenarios) (damage } \\
\text { points) }\end{array}$ & \multicolumn{2}{|c|}{ N/A } & $50 \%$ \\
\hline $\begin{array}{c}\text { McDowall et al. } \\
{[31]}\end{array}$ & Power sector & $\mathrm{CO}_{2}$ emissions & \multicolumn{2}{|c|}{ N/A } & $10 \%$ \\
\hline $\begin{array}{c}\text { Raugei et al. } \\
{[32]}\end{array}$ & Solar PV & GHG emissions $\left(\mathrm{TgCO}_{2} \mathrm{e} / \mathrm{yr}\right)$ & \multicolumn{2}{|c|}{ N/A } & $\pm 2 \%$ \\
\hline \multirow[t]{2}{*}{$\begin{array}{l}\text { Vandepaer et al. } \\
\text { [34] }\end{array}$} & $\begin{array}{l}\text { Lithium } \\
\text { metal } \\
\text { polymer } \\
\text { battery }\end{array}$ & \multirow[t]{2}{*}{$\begin{array}{l}\text { Climate change } \\
\left(\mathrm{kgCO}_{2} \mathrm{e} / \mathrm{MWh}\right)\end{array}$} & $7.89 *$ & -443 & $-5714 \%$ \\
\hline & $\begin{array}{l}\text { Li-ion } \\
\text { battery }\end{array}$ & & $6.68^{*}$ & -439 & $-6671 \%$ \\
\hline $\begin{array}{c}\text { Dandres et al. } \\
{[40]}\end{array}$ & $\begin{array}{l}\text { Electricity } \\
\text { and heat }\end{array}$ & Environmental impacts & \multicolumn{2}{|c|}{ N/A } & $5.5 \%$ \\
\hline
\end{tabular}

Notes:

N/A = Not available. No number on direct and indirect impacts was provided in the studies [25], [26], [29], [31], [32] and [40]. Instead, these authors presented the results on variations between "direct impact only" and "indirect impact inclusion".

* These numbers were estimated by the authors based on Figure 3 of Vandepaer et al. [34]. 
Igos et al. assessed the impacts on human health, ecosystem and resources of two energy policies: Business As Usual (BAU) and Greenhouse Gas (GHG). In the BAU policy, the drivers for change were socio-economic drivers, including growth rates of economic sectors, population and GDP. In the GHG policy, apart from socio-economic drivers, a reduction target of $2.5 \%$ was also considered. The environmental impacts included impacts from energy production and energy import as well as indirect impacts due to economic changes. The contribution of indirect impacts was up to $50 \%$ in all three categories of human health, ecosystem and resources. The environmental impacts in the GHG policy were 2-3\% lower than those in the BAU policy. This difference mainly and directly came from energy sector. The contribution of other economic sectors such as agriculture, construction, etc. to this 2-3\% difference was less than $0.1 \%$ [29].

Raugei et al. conducted a CLCA on increased uptake of solar PV in the UK grid. The increase of solar PV capacity influenced the generation mix as well as the grid development, and consequently global warming potential of solar PV [32]. The authors identified that there was a small difference in the GHG emissions from the increased solar PV deployment, which originated from background stages of solar PV and changes in the generation mix [30]. Consequently, any change in the solar PV deployment had no considerable additional emissions of the UK on-grid power, at around $\pm 2 \%$ [32].

Vandepaer et al. quantified the environmental impacts of inclusion of battery into the Swiss power system by 2030. In the current policy scenario, the inclusion of battery caused the displaced electricity mix, which was dominated by natural gas combined cycle units [34]. The inclusion of batteries generated environmental benefits in 12 of the 16 impact categories, including climate change, ozone depletion, particulate matter, ionizing radiation, photochemical ozone formation, acidification, terrestrial eutrophication, freshwater eutrophication, marine eutrophication, land use and water resource depletion. In low carbon scenario, marginal electricity generation being displaced due to the inclusion of batteries mostly came from geothermal and hydropower which already had reduced environmental impacts. Therefore, the environmental benefits due to the inclusion of battery are reduced as compared to those of current policy scenario [34]. Specifically, in the current policy scenario, the emission reductions of lithium metal polymer and Li-ion battery are 443 and $439 \mathrm{kgCO}_{2} \mathrm{e} / \mathrm{MWh}$, respectively. In the low carbon scenario, these numbers are less than $200 \mathrm{kgCO}_{2} \mathrm{e} / \mathrm{MWh}$ for both types of batteries [34].

Dandres et al. assessed the environmental impacts of EU electricity and heat generation in two EU energy policies, namely baseline and bioenergy, in consideration with and without global economic development. The quantified impacts included direct impacts of increased energy generation and indirect impacts due to change in the global economic activities served for increased energy generation in the EU. It was indicated that potential indirect impacts were higher than direct impacts, with impacts occurring inside the EU border only accounting for $5.5 \%$ of the total global potential impacts. Interestingly, indirect impacts of increased energy in bioenergy policy were considerably higher than those in baseline policy [40]. Bioenergy policy, which harnesses more renewable energy compared to baseline policy, should be cleaner. However, the obtained results indicated that it causes more environmental impacts due to the indirect consequences of bioenergy on global economic activities [40].
There is a link between the environmental and economic aspects of power sector. Any increase or decrease in the indirect environmental impacts of the power system will affect the cost for the system. Algunaibet et al. quantified the life cycle indirect cost of electricity generation in the US and pointed out that other indirect environmental impacts of power sector need to be considered apart from direct GHG emissions. In the study, the costs of electricity were minimized with constraints on demand, generation potential and capacity factor, while achieving a particular target on emission. These costs included levelized cost of electricity (direct cost) and costs to endpoint life cycle indicators including human health, ecosystem diversity and resource availability (indirect cost, externalities) [31]. It was found that by meeting the emission reduction of Paris Agreement, the indirect costs of electricity generation could be reduced up to $63 \%$ [31]. In contrast, the withdrawal from Paris Agreement would cause a cost up to $1103 \pm 206$ billion USD 2013 in BAU scenario by 2030 [31]. When both direct and indirect costs were optimized, the total cost for the energy system would be $373 \pm 164$ billion USD 2013 in 2030 [31].

Elzein et al. assessed the GHG emission and operating cost of electricity generation of Normandy grid with the inclusion of energy storage systems. The inclusion of energy storage systems altered the generation of thermal and nuclear power plant, consequently, reduced GHG emissions by 53\%. At the same time, the operating cost reduced by $28 \%$ as compared to the base case of historic power generation without energy storage systems [38].

\section{CONCLUSION}

The review of CLCA in power sector indicated the methodology's strength in precisely quantifying indirect environmental impacts of the product system due to socioeconomic changes during its life cycle thanks to the features of expansion of system boundary and inclusion of socioeconomic interactions.

The system boundary is expanded in all reviewed CLCA case studies, by taking into account unit processes, affected products and co-products, and economic sectors to the extent of changes. The affected products are treated differently among reviewed papers, either with ceteris paribus or mutatis mutandis assumptions. The ceteris paribus assumes that the scale of change is small and deals with the physical change without consideration of socio-economic impacts; therefore, studies using this type of assumption can be regarded as applying consequential concept.

Meanwhile, the mutatis mutandis assumption identifies a set of affected products with different scales of change. It also considers the socio-economic interactions between the investigated product system and the affected product. The mutatis mutandis assumption is made by reviewing existing literature, and more frequently, by applying one or several economic modelling tools.

The adoption of economic models and CLCA has the advantages of tracking the links between environmental impacts and socio-economic indicators, such as product demands or economic growth, domestic market or import/export market, and consumer behaviours.

With the application of CLCA, the total environmental impacts vary from negligible to considerable difference. In case of GHG emissions, when the indirect emissions are 
included, the investigated power becomes cleaner, less clean or more polluted. The magnitudes of the variations are vastly different among case studies, depending on the scopes of the studies and specific investigated product system. In most of the cases, the GHG emissions and other environmental impacts of power sector become larger with the application of CLCA, due to the inclusion of indirect environmental impacts on relevant economic sectors.

\section{REFERENCES}

[1] UNFCCC. (2020). Annual greenhouse gas (GHG) emissions for Annex $\mathrm{I}$, in $\mathrm{Gt} \mathrm{CO}_{2}$ equivalent. https://di.unfccc.int/comparison_by_category, accessed on July 2, 2020.

[2] IEA. (2020). Energy Transitions Indicators. https://www.iea.org/reports/energy-transitionsindicators, accessed on July 2, 2020.

[3] Carnevale, P., Mattei, FEE. (2020). Roadmap to 2050: A Manual for Nations to Decarbonize by Mid-Century. Sustainable Development Solutions Network.

[4] DDPP. (2015). Pathways to deep carbonization 2015 report. Deep Decarbonisation Pathways Project SDSN IDDRI.

[5] Luu, L.Q., Halog, A. (2016). Rice husk based bioelectricity vs. Coal-fired electricity: Life cycle sustainability assessment case study in Vietnam. $\begin{array}{lll}\text { Procedia } & \text { CIRP, } & \text { 70: }\end{array}$ https://doi.org/10.1016/j.procir.2016.01.058

[6] Longo, S., Mistretta, M., Guarino, F., Cellura, M. (2017). Life cycle assessment of organic and conventional apple supply chains in the North of Italy. Journal of Cleaner Production, 140(Part 2): 654-663. https://doi.org/10.1016/j.jclepro.2016.02.049

[7] Beccali, G., Cellura, M., Mistretta, M. (2001). Managing municipal solid waste energetic and environmental comparison among different management options. The International Journal of Life Cycle Assessment, 6(4): 243-249. https://doi.org/10.1007/BF02979380

[8] Horne, R.E. (2009). Life cycle assessment: Origins, Principles and Context. In Horne RE, Grant $\mathrm{T}$ and Verghese K (eds) Life Cycle Assessment - Principles Practice and Prospects, CSIRO Publishing.

[9] Bjørn, A., Owsianiak, M., Molin, C., Hauschild, M.Z. (2018). Chapter 3 LCA History. In: Hauschild MZ, Rosenbaum RK and Olsen SI (eds) Life Cycle Assessment, Springer International Publishing.

[10] Glasziou, P. (2013). Chapter 14 How to write a review. In: Hall G (eds) How to write a paper, John Wiley and Sons Publishing.

[11] Ekvall, T. (2002). Cleaner production tools: LCA and beyond. Journal of Cleaner Production, 10(5): 403-406. https://doi.org/10.1016/S0959-6526(02)00026-4

[12] Ekvall, T., Weidema, B.P. (2004). System boundaries and input data in consequential life cycle inventory analysis. International Journal of Life Cycle Assessment, 9: 161-171. https://doi.org/10.1007/BF02994190

[13] Curran, M.A., Mann, M., Norris, G. (2005). The international workshop on electricity data for life cycle inventories. Journal of Cleaner Production, 13(8): 853862. https://doi.org/10.1016/j.jclepro.2002.03.001

[14] Soimakallio, S., Kiviluoma, J., Saikku, L. (2004). The complexity and challenges of determining GHG (greenhouse gas) emissions from grid electricity consumption and conservation in LCA (life cycle assessment): A methodological review. Energy, 36(12): $6705-$

6713. https://doi.org/10.1016/j.energy.2011.10.028

[15] Earles, J.M., Halog, A. (2011). Consequential life cycle assessment: A review. International Journal of Life Cycle Assessment, 16: 445-453. https://doi.org/10.1007/s11367-011-0275-9

[16] Nielsen, P.H., Oxenboll, K.M., Wenzel, H. (2007). Cradel-to-gate environmental assessment of enzyme products produced industrially in Denmark by Novoaymes A/S. International Journal of Life Cycle Assessment, 12: 432-438. https://doi.org/10.1065/lca2006.08.265.1

[17] Roos, A., Ahlgren, S. (2018). Consequential life cycle assessment of bioenergy systems - A literature review. Journal of Cleaner Production, 189: 358-373. https://doi.org/10.1016/j.jclepro.2018.03.233

[18] Zamagni, A., Guinee, J., Heijungs, R., Masoni, P., Raggi, A. (2012). Lights and shadows in consequential LCA. International Journal of Life Cycle Assessment, 17: 904918. https://doi.org/10.1007/s11367-012-0423-x

[19] Sanchez, S.T., Woods, J., Akhurst, M., Brander, M., O'Hare, M., Dawson, T.P., Edwards, R., Liska, A.J., Malpas, R. (2012). Accounting for indirect land-use change in the life cycle assessment of biofuel supply chains. Journal of the Royal Society Interface, 9: 11051119. https://doi.org/10.1098/rsif.2011.0769

[20] Marvuglia, A., Benetto, E., Rege, S., Jury, C. (2013). Modelling approaches for consequential life-cycle assessment (C-LCA) of bioenergy: Critical review and proposed framework for biogas production. Renewable \& Sustainable Energy Reviews, 25: 768-781. https://doi.org/10.1016/j.rser.2013.04.031

[21] Weidema, B.P. (2003). Market information in life cycle assessment. Environmental Project no. 863. Danish Environmental Protection Agency, Copenhagen.

[22] Eriksson, O., Finnveden, G., Ekvall, T., Bjorklund, A. (2007). Life cycle assessment of fuels for district heating: A comparison of waste incineration, biomass- and natural gas combustion. Energy Policy, 35(2): 1346-1362. https://doi.org/10.1016/j.enpol.2006.04.005

[23] Pizarro-Alonso, A., Cimpan, C., Munnstr, M. (2018). The climate footprint of imports of combustible waste in systems with high shares of district heating and variable renewable energy. Waste Management, 79: 800-814. https://doi.org/10.1016/j.wasman.2018.07.006

[24] Moora, H., Lahtvee, V. (2009). Electricity scenarios for the Baltic states and marginal energy technology in life cycle assessments - A case study of energy production from municipal waste incineration. Oil Shale, 26: 331346. https://doi.org/10.3176/oil.2009.3S.14

[25] Pehnt, M., Oeser, M., Swider, D.J. (2008). Consequential environmental system analysis of expected offshore wind electricity production in Germany. Energy, 33(5): 747759. https://doi.org/10.1016/j.energy.2008.01.007

[26] Blanco, H., Codina, V., Laurent, A., Nijs, W., Marechal, F., Faaij, A. (2020). Life cycle assessment integration into energy system models: An application for Power-toMethane in the EU. Applied Energy, 259: 114160. https://doi.org/10.1016/j.apenergy.2019.114160

[27] Mathiesen, B.V., Munster, M., Fruergaard, T. (2009). Uncertainties related to the identification of the marginal 
energy technology in consequential life cycle assessments. Journal of Cleaner Production, 17(15): 1331-1338.

https://doi.org/10.1016/j.jclepro.2009.04.009

[28] Lund, H., Mathiesen, B.V., Christensen, P., Schmidt, J.H. (2010). Energy system analysis of marginal electricity supply in consequential LCA. International Journal of Life Cycle Assessment, 15: 260-271. https://doi.org/10.1007/s11367-010-0164-7

[29] Igos, E., Rugani, B., Rege, S., Benetto, E., Drouet, L., Zachary, D.S. (2015). Combination of equilibrium models and hybrid life cycle-input-output analysis to predict the environmental impacts of energy policy scenarios. Applied Energy, 145: 234-245. https://doi.org/10.1016/j.apenergy.2015.02.007

[30] Gibon, T., Hertwich, E.G., Arvesen, A., Singh, B., Verones, F. (2017). Health benefits, ecological threats of low-carbon electricity. Environmental Research Letters, 12(3). https://doi.org/10.1088/1748-9326/aa6047

[31] McDowall, W., Rodriguez, B.S., Usubiaga, A., Fernandez, J.A. (2018). Is the optimal decarbonisation pathway influenced by indirect emissions? Incorporating indirect life-cycle carbon dioxide emissions into a European TIMES model. Journal of Cleaner Production, 170: 260-268. https://doi.org/10.1016/j.jclepro.2017.09.132

[32] Raugei, M., Leccisi, E., Azzopardi, B., Jones, C., Gilbert, P., Zhang, L.X, Zhou, Y.T., Mander, S., Mancarella, P. (2018). A multi-disciplinary analysis of UK grid mix scenarios with large-scale PV deployment. Energy Policy, 114: 51-62. https://doi.org/10.1016/j.enpol.2017.11.062

[33] Algunaibet, I.M., Pozo, C., Galan-Martin, A., GuillenGosalbez, G. (2019). Quantifying the cost of leaving the Paris Agreement via the integration of life cycle assessment, energy systems modeling and monetization. Applied 242: 5nergy, 588-601. https://doi.org/10.1016/j.apenergy.2019.03.081

[34] Vandepaer, L., Cloutier, J., Bauer, C., Amor, B. (2019). Integrating batteries in the future swiss electricity supply system: A consequential environmental assessment. Journal of Industrial Ecology, 23(3): 709-725. https://doi.org/10.1111/jiec.12774

[35] Weidema, B.P., Frees, N., Nielsen, A.M. (1999). Marginal production technologies for life cycle inventories. International Journal of LCA, 4: 48-56. https://doi.org/10.1007/BF02979395

[36] Cusenza, M.A., Guarino, F., Longo, S., Mistretta, M., Cellura, M. (2020). Environmental assessment of 2030 electricity generation scenarios in Sicily: An integrated approach. Renewable Energy, 160: 1148-1159. https://doi.org/10.1016/j.renene.2020.07.090

[37] Frischknecht, R., Stucki, M. (2010). Scope-dependent modelling of electricity supply in life cycle assessments. International Journal of Life Cycle Assessment, 15: 806816. https://doi.org/10.1007/s11367-010-0200-7

[38] Weidema, B.P., Ekvall, T., Heijungs, R. (2009). Guidelines for application of deepened and broadened LCA. Project no. 037075, Co-ordination Action for innovation in Life-Cycle Analysis for Sustainability CALCAS, The Italian National Agency on new Technologies, Energy and the Environment, ENEA.
[39] Jones, C., Gilbert, P., Raugei, M., Mander, S., Leccisi, E. (2017). An approach to prospective consequential life cycle assessment and net energy analysis of distributed electricity generation. Energy Policy, 100: 350-258. https://doi.org/10.1016/j.enpol.2016.08.030

[40] Dandres, T., Gaudreault, C., Tirado-Seco, P., Samson, R. (2011). Assessing non-marginal variations with consequential LCA: Application to European energy sector. Renewable \& Sustainable Energy Reviews, 15(6): 3121-3132. https://doi.org/10.1016/j.rser.2011.04.004

[41] Elzein, H., Dandres, T., Levasseur, A., Samson, R. (2019). How can an optimized life cycle assessment method help evaluate the use phase of energy storage systems? Journal of Cleaner Production, 209: 1624-1636. https://doi.org/10.1016/j.jclepro.2018.11.076

[42] Choi, J.K., Friley, P., Alfstad, T. (2012). Implication of energy policy on a product system's dynamic life-cycle environmental impact: survey and model. Renewable and Sustainable Energy Reviews, 16(7): 4744-4752. https://doi.org/10.1016/j.rser.2012.05.032

[43] Jones, C., Gilbert, P. (2018). Determining the consequential life cycle greenhouse gas emissions of increased rooftop photovoltaic deployment. Journal of Cleaner Production, 184: 211-219. https://doi.org/10.1016/j.jclepro.2018.02.140

[44] Florent, Q., Enrico, B. (2015). Combining agent based modeling and life cycle assessment for the evaluation of mobility policies. Environmental Science and Technology, 49(3): 1744-1751. https://doi.org/10.1021/es5060868

[45] Onat, N.C., Kucukvar, M., Tatari, O. (2016). Uncertainty-embedded dynamic life cycle sustainability assessment framework: An ex-ante perspective on the impacts of alternative vehicle options. Energy, 112: 715728. https://doi.org/10.1016/j.energy.2016.06.129

[46] Luu, L.Q., Longo, S., Cellura, M., Sanseverino, E.R., Cusenza, M.A., Franzitta, V.A. (2020). Conceptual review on using consequential life cycle assessment methodology for the energy sector. Energies, 13(12): 3076. https://doi.org/10.3390/en13123076

[47] Hammond, G.P., O'Grady, A. (2017). The potential environmental consequences of shifts in UK energy policy that impact on electricity generation. Proceedings of the Institution of Mechanical Engineers Part a-Journal of Power and Energy, 231(6): 535-550. https://doi.org/10.1177/0957650916675519

[48] Beaussier, T., Cairla, S., Maurel, V.B., Loiseau, E. (2019). Coupling economic models and environmental assessment methods to support regional policies: A critical review. Journal of Cleaner Production, 216: 408421. https://doi.org/10.1016/j.jclepro.2019.01.020

[49] Cellura, M., Guarino, F., Longo, S., Mistretta, M., Orioli, A. (2013). The role of the building sector for reducing energy consumption and greenhouses gases: An Italian case study. Renewable Energy, 60: 586-597. https://doi.org/10.1016/j.renene.2013.06.019

[50] Luu, L.Q., Longo, S., Cellura, M., Sanseverino, E.R. (2020). CLCA for assessing environmental impacts of power sector in the GHG policy context. TECNICA ITALIANA-Italian Journal of Engineering Science, 64(2-4): 229-238. https://doi.org/10.18280/ti-ijes.642416 
NOMENCLATURE

$\begin{array}{ll}\text { ABM } & \text { Agent Based Modelling } \\ \text { ALCA } & \text { Attributional Life Cycle Assessment } \\ \text { BAU } & \text { Business as usual } \\ \text { CCS } & \text { Carbon Capture and Storage } \\ \text { CHP } & \text { Combined heat power } \\ \text { CLCA } & \text { Consequential Life Cycle Assessment } \\ \text { DM } & \text { Dynamic model } \\ \text { E2M2 } & \text { EU Electricity Market Model } \\ \text { EEIO } & \text { Environmentally Extended Input Output } \\ \text { EU } & \text { European } \\ \text { EV } & \text { Electric Vehicles } \\ \text { gCO } 2 & \text { Gram carbon dioxide } \\ \text { GDP } & \text { Gross Domestic Product } \\ \text { GE } & \text { General equilibrium } \\ \text { GHG } & \text { Greenhouse Gas } \\ \text { GTAP } & \text { Global Trade Analysis Project }\end{array}$

$\mathrm{GtCO}_{2} \mathrm{e}$

GW

ha

IO

$\mathrm{kWh}$

LCA

LR

NEA

PE

PV

SD

STEM

$\mathrm{tCO}_{2} \mathrm{e}$

TWh

UK

US

V2G

tPe

USD
Giga ton of carbon dioxide equivalent Giga watt

Hectare

Input Output

Kilo watt hour

Life Cycle Assessment

Literature review

Net Energy Analysis

Partial equilibrium

Photovoltaics

System Dynamics

Swiss TIMES Energy Model

Ton of carbon dioxide equivalent

Tera watt hour

United Kingdom

United State of America

Vehicle to Grid

Ton of phosphorus equivalent

US dollar 